\title{
Dochody z działalności gospodarczej samorządu terytorialnego na tle międzywojennych rozwiązań prawnych
}

\section{Income from economic activities of local self-government against the interwar legal solutions}

Streszczenie. W opracowaniu podjęto problematykę dochodów z działalności gospodarczej jednostek samorządu terytorialnego w Polsce. Jego bezpośrednim celem jest analiza i ocena wybranych rozwiązań prawnych odnoszących się do zagadnienia dochodów z działalności gospodarczej samorządu terytorialnego aktualnie obowiązujących oraz ustanowionych w okresie II RP. Z zagadnieniami tymi ściśle związana jest kwestia dopuszczalnego zakresu tej działalności gospodarczej: w okresie II RP j.s.t. dysponowały w zasadzie pełną swobodą w dziedzinie gospodarki lokalnej - dziś jest inaczej, ustawodawca ustanowił bowiem zakazy i ograniczenia odnoszące się do działalności gospodarczej j.s.t. wykraczającej poza sferę użyteczności publicznej. W czasach II RP działały ponadto interesujące instytucje - komunalne kasy oszczędności. Współcześnie działają one także w wielu krajach Europy (np. w Niemczech). Z niewiadomych przyczyn - kasy nie istnieją obecnie w Polsce. 
Słowa kluczowe: działalność gospodarcza; samorząd terytorialny; komunalne kasy oszczędności.

\begin{abstract}
The study takes up the problem of income from economic activities of local self-government units in Poland. Its direct goal is to analyse and evaluate selected legal solutions that address issues of income from economic activities of local government - solutions being currently in force and those established in the Second Republic of Poland. Closely related with these issues is the matter of the acceptable scope of those economic activities: during the Second Republic of Poland l.g.u. practically had total freedom in the field of local economy available - today it is different, because the legislature established prohibitions and restrictions relating to the economic activities of the l.g.u. extending beyond the area of public utility. Additionally, during the Second Republic of Poland interesting institutions have been functioning - municipal savings banks. Today they operate in many European countries (eg. in Germany). For unknown reasons - such banks does not currently exist in Poland.
\end{abstract}

Keywords: economic activity; local self-government; municipal savings banks.

\title{
1. Wprowadzenie
}

Zgodnie z Konstytucją Rzeczypospolitej Polskiej z dnia 2 kwietnia 1997 r. ${ }^{1}$ samorząd terytorialny wykonuje, na zasadach samodzielności, istotną część zadań publicznych (por. art. 16 ust. 2, art. 163, 165 ust. 2). Samodzielność stanowi konstytutywną cechę samorządu terytorialnego, podkreślaną przez przedstawicieli nauki w czasach historycznych oraz współczesnych $^{2}$. Wyraża się ona m.in. w uprawnieniu jednostek samorządu

Dz.U. Nr 78, poz. 483 ze zm (dalej: Konstytucja RP z 1997 r.).

Zob. np.: T. Bigo, Zwiqzki publiczno-prawne $w$ świetle ustawodawstwa polskiego, Warszawa 1928, s. 152; Z. Janku, Samodzielność jednostek samorzq̨du terytorialnego $a$ istota nadzoru, ze szczególnym uwzględnieniem nadzoru regionalnej izby obrachunkowej, s. 62 i n.; A. Skibiński, Samodzielność samorzq̨du terytorialnego w Polsce w świetle ukształtowanego nadzoru, s. 202 i n., [w:] J. Małecki, R. Hauser, Z. Janku (red.), 15 lat funkcjonowania izb obrachunkowych, Poznań 2007; M. Kotulski, Pojęcie $i$ istota samorzq̨du terytorialnego, „Samorząd Terytorialny” 2000, nr 1-2, s. 82 i n. (autor dokonuje analizy sposoby definiowania i rozumienia istoty samorządu terytorialnego w okresie międzywojennym i współcześnie). 
terytorialnego $^{3}$ (dalej: j.s.t.) do gromadzenia - na zasadach określonych przez prawo - środków finansowych potrzebnych na realizację zadań samorządowych ${ }^{4}$. Jednym ze źródeł dochodów samorządu terytorialnego są wpływy uzyskiwane z prowadzonej przez gminy, powiaty i województwa działalności gospodarczej; z analizy literatury i aktów prawnych wynika, że źródło to należy do ich najstarszych źródeł dochodowych. Już bowiem w początkowym okresie istnienia samorządu terytorialnego na ziemiach polskich (przypadającym na okres zaborów) jednostki tego samorządu mogły czerpać dochody z działalności prowadzonej w sferze gospodarki lokalnej ${ }^{5}$ (por. np.: art. 14 ukazu cara Aleksandra II z 24 maja/5 czerwca 1861 r. o radach gubernialnych ${ }^{6}$, art. 15, 19 ukazu cara Aleksandra II z 24 maja/5 czerwca 1861 r. o radach powiatowych ${ }^{7}$, art. 18, 28 ukazu cara Aleksandra II z 24 maja/5 czerwca 1861 r. o radach miejskich $^{8}$, art. 16 pkt b ukazu cara Aleksandra II z 19 lutego/2 marca 1864 r.

3 W okresie II RP j.s.t. określano „jednostkami samorządu terytorialnego”, częściej „Związkami komunalnymi” oraz „związkami samorządowymi”, por. np. art. 65 Konstytucji Rzeczypospolitej Polskiej z dnia 17 marca 1921 r. (Dz.U. Nr 44, poz. 267 ze zm., dalej: Konstytucja marcowa), § 1 rozporządzenia Prezydenta Rzeczypospolitej z dnia 17 czerwca 1924 r. o obowiązku pokrywania wydatków przez związki komunalne (Dz.U. Nr 51, poz. 522 ze zm.), art. 1 ust. 6 ustawy dnia 23 marca 1933 r. o częściowej zmianie ustroju samorządu terytorialnego (Dz.U. Nr 35, poz. 294 ze zm. - dalej: ustawa scaleniowa). Dla jasności rozważań autorzy niniejszego opracowania będą posługiwać się w terminologią współcześnie używaną.

4 Zob. np.: L.W. Biegeleisen, Zagadnienia ekonomiki komunalnej, Warszawa 1928, s. 5, 44 i n.; R. Rybarski, Nauka skarbowości, Warszawa 1935, s. 387; C. Kosikowski, Finanse publiczne $w$ świetle Konstytucji RP oraz orzecznictwa Trybunału Konstytucyjnego, Warszawa 2004, s. 222-223; A. Borodo, Samorzq̨d terytorialny. System prawnofinansowy, Warszawa 2004, s. 36-37.

5 Zob. np. B. Markowski, Finanse samorzqdu terytorialnego (1919-1928) (w:) S.L. Zaleski (red.), Bilans gospodarczy dziesięciolecia Polski odrodzonej, Poznań 1929, s. 295 i n.

Pojęcia „gospodarka lokalna” i „gospodarka komunalna” należy traktować równoznacznie.

Dziennik Praw Królestwa Polskiego, t. 58, s. 276-293 (dalej: DPKP).

DPKP, t. 58, s. 294-327.

8 DPKP, t. 58, s. 328-363. Inicjatorem utworzenia rad w 1861 r. był A. Wielopolski polski arystokrata-ziemianin, sprawujący w Królestwie Polskim funkcję naczelnika rządu cywilnego (szerzej na temat rad A. Wielopolskiego zob. np. B. Kołaczkowski, M. Ratajczak, Samorzqd terytorialny w zaborze rosyjskim? Poczq̨tki decentralizacji administracji terenowej w Królestwie Polskim i na Ziemiach Zabranych w latach 18611915, „Samorząd Terytorialny” 2013 nr 7-8, s. 156-158 i powołaną tam literaturę). 
o urządzeniu gmin wiejskich ${ }^{9}$, § 26, 27, 30 ustawy krajowej z 12 sierpnia 1866 r. o urządzeniu gmin i ordynacji wyborczej dla gmin ${ }^{10}$, § 20, 21, 30 ustawy krajowej z 12 sierpnia 1866 r. o reprezentacji powiatowej i ordynacji wyborczej powiatowej) ${ }^{11}$. Należy jednak zauważyć, że działalność gospodarcza samorządu terytorialnego w pełni rozwinęła się naturalnie dopiero w II Rzeczypospolitej ${ }^{12}$.

Wstępna analiza aktualnie obowiązujących w Polsce i międzywojennych regulacji prawnych odnoszących się do działalności gospodarczej samorządu terytorialnego pozwala sformułować tezę, że współcześnie j.s.t. dysponują węższym zakresem swobody w prowadzeniu działalności gospodarczej niż j.s.t. w czasach międzywojennych, co przedkłada się na bardziej ograniczone możliwości osiągania dochodów z tej działalności. Zasadniczym celem niniejszego opracowania jest zatem analiza i ocena rozwiązań prawnych odnoszących się do zagadnienia dochodów z działalności gospodarczej samorządu terytorialnego aktualnie obowiązujących oraz ustanowionych w okresie II RP.

\section{Podstawy prawne dochodów z działalności gospodarczej samorządu terytorialnego}

Regulacjami prawnymi mającymi podstawowe znaczenie przy kształtowaniu wysokości dochodów z działalności gospodarczej samorządu terytorialnego są w aktualnym stanie prawnym:

- $\quad$ Konstytucja RP z 1997 r., ustawa z dnia 8 marca 1990 r. o samorządzie gminnym ${ }^{13}$, ustawa z dnia 5 czerwca 1998 r. o samorządzie po-

\footnotetext{
9 DPKP, t. 62, s. 36-93.

10 Zbiór ustaw, Piwocki, t. 1, s. 328-372.

11 Zbiór ustaw, Piwocki, t. 1, s. 456-483. Wyjątki wymienionych aktów prawnych zamieszczone zostały np. w opracowaniu: M. Kallas, M. Krzymkowski, Historia ustroju i prawa w Polsce 1772/1795-1918, Warszawa 2006.

12 Zob. np. A. Dmitrjew, Przedsiębiorstwa komunalne w ustawodawstwie polskiem (studjum finansowe), Wilno 1934, s. 6.

Nazwa „II Rzeczpospolita” będzie stosowana zamiennie z ogólnie przyjętym skrótem „II RP”.

13 Tekst jedn. Dz.U. z 2016 r., poz. 446 ze zm. (dalej: ustawa o samorządzie gminnym).
} 
wiatowym ${ }^{14}$ oraz ustawa z dnia 5 czerwca 1998 r. o samorządzie województwa ${ }^{15}$ - wyznaczają one m.in. zakres działania poszczególnych j.s.t., kompetencje organów samorządowych, w tym kompetencje finansowe, kompetencje do tworzenia, przekształcania lub likwidacji przedsiębiorstw samorządowych,

- $\quad$ ustawa z dnia 13 listopada 2003 r. o dochodach jednostek samorządu terytorialnego ${ }^{16}$ - ustawa ta określa źródła dochodów j.s.t. oraz zasady ustalania i gromadzenia tych dochodów,

- $\quad$ ustawa z dnia ustawa z dnia 20 grudnia 1996 r. o gospodarce komunalnej ${ }^{17}$ - określa ona zasady i formy gospodarki komunalnej,

- $\quad$ ustawa z dnia 27 sierpnia 2009 r. o finansach publicznych ${ }^{18}$ - wyznacza zasady prowadzenia publicznej, a zatem także samorządowej, gospodarki finansowej.

Z uwagi na zamierzenie przeprowadzenia analiz porównawczych rozwiązań prawnych aktualnie obowiązujących z rozwiązaniami przyjętymi w omawianej dziedzinie w okresie II RP konieczne jest przedstawienie podstaw prawnych dochodów z działalności gospodarczej międzywojennego samorządu terytorialnego ${ }^{19}$. W II RP głównymi źródłami prawa

\footnotetext{
Tekst jedn. Dz.U. z 2016 r., poz. 814 ze zm. (dalej: ustawa o samorządzie powiatowym). Tekst jedn. Dz.U. z 2016 r., poz. 486 ze zm. (dalej: ustawa o samorządzie województwa). Tekst jedn. Dz.U. z 2016 r., poz. 198 ze zm. (dalej: ustawa o dochodach j.s.t.).

Tekst jedn. Dz.U. z 2016 r., poz. 573 ze zm.

Tekst jedn. Dz.U. z 2013 r., poz. 885 ze zm. (dalej: ustawa o finansach publicznych).

19 W okresie II RP samorząd terytorialny działał w gminach, miastach, powiatach, a na terenach b. zaboru pruskiego także w województwach (pomorskim i wielkopolskim), będąc spadkobiercą pruskich sejmików prowincjonalnych. Podobnie jak w III RP, w okresie II RP j.s.t. miały nadaną osobowość prawną, dysponowały własnym mieniem, prowadziły samodzielną (opartą na budżetach j.s.t.) gospodarkę finansową, por. np.: art. 65 Konstytucji marcowej, art. 2 dekretu z dnia 4 lutego 1919 r. o samorządzie miejskim (Dz.U. Nr 13, poz. 140 ze zm., dalej: dekret z 1919 r. o samorządzie miejskim), art. 1 ust. 1 dekretu z dnia 4 lutego 1919 r. o tymczasowej ordynacji powiatowej dla obszarów Polski byłego zaboru rosyjskiego (Dz.U. Nr 13, poz. 141 ze zm.) - dalej: ordynacja powiatowa z 1919 r., art. 10 ust. 3 ustawy scaleniowej, § 1 rozporządzenia Prezydenta Rzeczypospolitej z dnia 17 czerwca 1924 r. o obowiązku i sposobie pokrywania wydatków przez związki komunalne). Szerzej na temat ustroju samorządu terytorialnego w II RP zob. np. W. Witkowski, Historia administracji w Polsce 1764-1989, Warszawa 2007, s. 341 i n.
} 
normującymi zagadnienie dochodów z działalności gospodarczej samorządu terytorialnego były:

- $\quad$ ustawa z dnia z dnia 11 sierpnia 1923 r. o tymczasowem uregulowaniu finansów komunalnych ${ }^{20}$ - ustawa ta, mimo zastrzeżenia w tytule tymczasowego jej charakteru, przetrwała (przy wielokrotnych nowelizacjach ${ }^{21}$ ) do końca okresu międzywojennego i była zasadniczym aktem prawnym ustalającym źródła dochodów j.s.t.,

- regulacje ustrojowe $\mathrm{z}$ zakresu samorządu terytorialnego (por. np. przepisy ustawy scaleniowej) oraz

- regulacje wyznaczające ogólne zasady gospodarki finansowej samorządu terytorialnego - należały do nich przede wszystkim rozporządzenie Prezydenta RP z dnia 17 czerwca 1924 r. o obowiązku i sposobie pokrywania wydatków przez związki komunalne (dalej: rozporządzenie Prezydenta RP z 1924 r. o obowiązku i sposobie pokrywania wydatków przez związki komunalne) oraz wydane do niego rozporządzenia wykonawcze ${ }^{22}$.

Istotną rolę przy prowadzeniu gospodarki finansowej j.s.t., w tym gromadzeniu przez nie dochodów z samorządowej działalności gospodarczej, odgrywały także okólniki (instrukcje) wydane przez władze rządowe (Ministra Spraw Wewnętrznych) ${ }^{23}$. Zaznaczyć należy, że w okresie II RP

20 Dz.U. Nr 94, poz. 747 ze zm. (dalej: ustawa o tymczasowym uregulowaniu finansów komunalnych).

21 Według A.W. Zawadzkiego, ustawa o tymczasowym uregulowaniu finansów komunalnych była nowelizowana aż 44 razy (zob. A.W. Zawadzki, Finanse samorzqdu w latach 1918-1939, Warszawa 1971, s. 54).

22 Wymienić tu należy przede wszystkim dwa rozporządzenia, tj.: rozporządzenie Ministra Spraw Wewnętrznych z dnia 28 czerwca 1926 r. wydane w porozumieniu z Ministrem Skarbu w sprawie wykonania § 11 punkt b) rozporządzenia Prezydenta Rzeczypospolitej z dnia 17 czerwca 1924 r. o obowiązku i sposobie pokrywania wydatków przez związki komunalne oraz niektórych innych paragrafów tegoż rozporządzenia Prezydenta Rzeczypospolitej (Dz.U. Nr 75, poz. 433 ze zm., dalej: rozporządzenie Ministra Spraw Wewnętrznych z dnia 28 czerwca 1926 r.) oraz rozporządzenie Ministra Spraw Wewnętrznych z dnia 6 grudnia 1932 r. wydane w porozumieniu z Ministrem Skarbu o sporządzaniu i ustalaniu budżetów związków komunalnych (Dz.U. z 1933 r. Nr 11, poz. 71 ze zm., dalej: rozporządzenie Ministra Spraw Wewnętrznych z dnia 6 grudnia 1932 r.).

23 Charakter wspomnianych okólników (instrukcji władzy rządowej, a nie aktu normatywnego) wyjaśniał np. L. Starzyński (zob. L. Starzyński, Prawo budżetowe 
nie wprowadzono aktu prawnego określającego zasady i formy prowadzenia gospodarki samorządu terytorialnego, a więc aktu prawnego odpowiadającego treścią ustawie z dnia 20 grudnia 1996 r. o gospodarce komunalnej (dalej: ustawa o gospodarce komunalnej).

\section{3. Źródła dochodów z działalności gospodarczej samorządu terytorialnego}

Jak sygnalizowano (zob. pkt. 1), działalność gospodarcza stanowi, zarówno w perspektywie historycznej, jak i współcześnie, jedno z tradycyjnych źródeł dochodów samorządów terytorialnych, por. np. art. 11 dekretu z 1919 r. o samorządzie miejskim, art. 7 ordynacji powiatowej z 1919 r., art. 1 rozporządzenia Prezydenta RP z dnia 16 marca 1928 r. o zaopatrywaniu mieszkańców w wodę ${ }^{24}$, art. 27 ust. 1, art. 28 ust. 2, art. 29 ust. 1 ustawy o tymczasowym uregulowaniu finansów komunalnych, art. 7 ust. 1 pkt 2, 3, 4, 7, 10, 15 ustawy o samorządzie gminnym, art. 4 ust. 1 pkt 6, 14, 19 ustawy o samorządzie powiatowym, art. 11 ust. 2 pkt. 2, art. 14 ust. 1 pkt 6, 9, 10 ustawy o samorządzie województwa, art. 7-8, 18 ustawy z dnia 16 grudnia 2010 r. o publicznym transporcie zbiorowym $^{25}$, art. 4 ust. 1 pkt 3-4, art. 5 ust. 1 pkt 23, art. 6 ust. 1 pkt $1-2$ ustawy o dochodach j.s.t. ${ }^{26} \mathrm{~W}$ aktualnym stanie prawnym prowadzenie przez j.s.t. działalności gospodarczej i osiąganie z niej dochodów podlega w Polsce określonym restrykcjom. Odnoszą się one do dwóch zagadnień, a mianowicie do zakresu działalności gospodarczej j.s.t. oraz form organizacyjno-prawnych, w jakich ta działalność może być wykonywana. Za pożądaną, dozwoloną i konieczną współczesny prawodawca polski oraz przedstawiciele nauki uznają działalność gospodarczą samorządu

zwiq̨zków samorzq̨dowych, [w:] L. Starzyński i F. Grela, Prawo budżetowe oraz przepis o kasowości i rachunkowości zwiqzzków samorzq̨dowych, Warszawa 1933, s. 9).

Dz.U. Nr 32, poz. 310 ze zm.

Tekst jedn. Dz.U. z 2015 r., poz. 1440 ze zm.

Zob. też unormowania prawne z okresu zaborów, przytoczone w pkt 1 niniejszego opracowania. 
terytorialnego o charakterze użyteczności publicznej ${ }^{27}$. W myśl ustawy o gospodarce komunalnej, zadania o charakterze użyteczności publicznej są to zadania, których celem jest bieżące i nieprzerwane zaspokajanie zbiorowych potrzeb ludności w drodze świadczenia usług powszechnie dostępnych (por. art. 1 ust. 2 ustawy) ${ }^{28}$. Analiza regulacji prawnych prowadzi do wniosku, że j.s.t. prowadząc działalność gospodarczą o charakterze użyteczności publicznej, dysponują szerokim zakresem swobody. To bowiem organy stanowiące tych jednostek dokonują wyboru sposobu i form realizacji zadań z tej sfery (por. art. 4 ust. 1 pkt 1 ustawy o gospodarce komunalnej). Jednostki samorządu terytorialnego mogą zatem samodzielnie prowadzić działalność gospodarczą o charakterze użyteczności publicznej (korzystając z formy samorządowego zakładu budżetowego $^{29}$, a więc finansując zadanie $\mathrm{w}$ ramach samorządowej

27 Zob. np.: S. Czarnow, Działalność gospodarcza jednostek samorzq̨du terytorialnego,” „Samorząd Terytorialny” 2007, nr 10, s. 22 i n.; A. Borodo, Samorzq̨d terytorialny. System prawnofinansowy, Warszawa 2012, s. 157 i n.; M. Kulesza, Gospodarka komunalna - podstawy i mechanizmy prawne, [w:] H. Izdebski, A. Nelicki, I. Zachariasz (red. nauk.), Finanse komunalne a Konstytucja, Warszawa 2012, s. 112113. Akceptowanie przez prawodawcę prowadzenia spraw z zakresu użyteczności publicznej wynika z treści przepisów ustawy o gospodarce komunalnej oraz np. przytoczonych norm samorządowych ustaw ustrojowych.

Podobne rozumienie pojęcia „zadania użyteczności publicznej” prawodawca zawarł w ustawie o samorządzie gminnym. Według art. 9 ust. 4 tej ustawy gminnymi zadaniami użyteczności publicznej są zadania własne gminy, których celem jest bieżące i nieprzerwane zaspokajanie zbiorowych potrzeb ludności w drodze świadczenia usług powszechnie dostępnych.

Nie wszystkie zadania własne jednostek samorządu terytorialnego mogą być uznane za zadania o charakterze użyteczności publicznej. Działalność spółki obejmująca udzielanie poręczeń pożyczek i kredytów zaciąganych przez jednostki samorządu terytorialnego nie wykazuje koniecznych elementów dla uznania takiej działalności jako realizacji zadania o charakterze użyteczności publicznej. Tego rodzaju działalności nie można bowiem uznać za formę realizacji zadań mających na celu bieżące i nieprzerwane zaspokajanie zbiorowych potrzeb wspólnoty (wyrok Naczelnego Sądu Administracyjnego w Warszawie z dnia 16 maja 2006 r., II OSK 288/06, OwSS 2006 nr 4, poz. 108).

Zastosowanie formy samorządowego zakładu budżetowego jest możliwe tylko w samorządowych jednostkach organizacyjnych, które wykonują zadania własne j.s.t. w dziedzinach określonych w art. 14 ustawy o finansach publicznych. Działanie tych jednostek oparte jest na zasadzie samofinansowania, tzn. pokrywania kosztów swojej działalności z przychodów własnych. Samorządowe zakłady budżetowe mogą - na zasadach prawnie określonych - otrzymywać dotacje z budżetu samorządowego (por. 
gospodarki budżetowej lub z formy spółki prawa handlowego, której kapitał stanowi całkowitą własność założycielskiej j.s.t.) albo współpracując $\mathrm{z}$ innymi podmiotami, tj. innymi j.s.t., organami administracji państwowej, osobami fizycznymi, osobami prawnymi oraz jednostkami organizacyjnymi nieposiadającymi osobowości prawnej. Współpraca ta może polegać np. na tworzeniu związku międzykomunalnego lub przystępowaniu do istniejącego związku ${ }^{30}$, zawieraniu porozumień $\mathrm{z}$ innymi j.s.t. $\mathrm{w}$ sprawie powierzenia wykonywania określonych zadań publicznych, zawieraniu umów cywilnoprawnych czy wreszcie, współtworzeniu spółki prawa handlowego (por. np. art. 2, 3, 6, 9 ustawy o gospodarce komunalnej, art. 8 ust. 2a, art. 9 ust. 1, art. 10, art. 18 ust. 1 pkt 9 f, art. 64 ust. 1, art. 74 ust. 1 ustawy o samorządzie gminnym, art. 5 ust. 2, art. 6 ust. 1, art. 7a, art. 12 pkt $8 \mathrm{f}-\mathrm{i}$, art. 65 ust. 1, art. 73, art. 74 ustawy o samorządzie powiatowym, art. 8 ust. $1-2$, art. 13 ust. 1 , art. 18 pkt 18, 19e-f ustawy samorządzie województwa, art. 19 ustawy o publicznym transporcie zbiorowym) $)^{31}$. Organy stanowiące j.s.t. postanawiają także o wysokości cen i opłat za usługi komunalne o charakterze użyteczności publicznej (lub o sposobie ustalania tych cen i opłat) oraz za korzystanie z obiektów i urządzeń użyteczności publicznej j.s.t. (por. np. art. 4 ust. 1 pkt 2 ustawy

art. 15 ust. 1, ust. 3-7 ustawy o finansach publicznych). Ustawa o gospodarce komunalnej wymienia samorządowy zakład budżetowy jako jedną z dwóch (obok spółki prawa handlowego) form w szczególności nadającej się do wykonywania zadań o charakterze użyteczności publicznej. W analizowanej formie organizacyjno-prawnej nie może być prowadzona przez j.s.t. działalność gospodarcza wykraczająca poza sferę użyteczności publicznej (por. art. 2, 7 ustawy o gospodarce komunalnej). Za niedopatrzenie prawodawcy uznaje się nieustanowienie zakazu prowadzenia tego typu działalności gospodarczej w formie samorządowej jednostki budżetowej (zob. np. M. Szydło, Ustawa o gospodarce komunalnej. Komentarz, Warszawa 2008, Komentarz do art. 2 ustawy o gospodarce komunalnej, LEX nr 37176). Szerzej na temat samorządowego zakładu budżetowego zob. np.: A. Borodo, Samorzq̨d terytorialny..., 2012, s. 209-210; B. Kołaczkowski, M. Ratajczak, Gospodarka finansowa samorzqdu terytorialnego w Polsce, Warszawa 2010, s. 68-70.

$30 \mathrm{~W}$ świetle obowiązujących przepisów prawnych możliwe jest tworzenie związków międzygminnych i związków zawieranych między powiatami, prawo nie dopuszcza natomiast tworzenia związków województw lub związków z udziałem województw.

31 Szerzej zob. np.: A. Borodo, Samorzqd terytorialny..., 2012, s. 161-163; M. Szydło, Ustawa o gospodarce..., Komentarz do art. 2 ustawy o gospodarce komunalnej. 
o gospodarce komunalnej, art. 6 ust. 2, art. 6k, 6l ustawy z dnia 13 września 1996 r. o utrzymaniu czystości i porządku w gminach ${ }^{32}$ ), przy czym uprawnienia dotyczące kształtowania cen i opłat organy stanowiące mogą powierzyć organom wykonawczym (por. art. 4 ust. 2 ustawy o gospodarce komunalnej). Należy jednak podkreślić, że z analizy zarówno literatury, jak i orzecznictwa wynika, że działalność gospodarcza j.s.t. w sferze użyteczności publicznej nie powinna być - z uwagi na specyfikę zadań użyteczności publicznej (zaspokajanie elementarnych często potrzeb mieszkańców wspólnot samorządowych) - nastawiona na osiąganie zysku (inaczej: na cel zarobkowy) ${ }^{33}$.

Jak wspomniano, restrykcje w sferze działalności gospodarczej j.s.t. dotyczą jej zakresu. I tak, istotne ograniczenia współczesny prawodawca polski ustanowił w dziedzinie działalności gospodarczej samorządu terytorialnego wykraczającej poza sferę użyteczności publicznej, czyli działalności gospodarczej nastawionej na osiąganie dochodów, tzw. komercyjnej działalności gospodarczej j.s.t. Spośród trzech wspólnot samorządowych działalność taką mogą prowadzić - wyłącznie w przypadkach wskazanych w ustawie i tylko w formie określonych spółek prawa handlowego - gminy i województwa (por. art. 7, 10 ust. 1-3 ustawy o gospodarce komunalnej) $)^{34}$. W odniesieniu do gminy jeden z tych przypadków dotyczy sytuacji, gdy istnieją niezaspokojone potrzeby wspólnoty samorządowej na rynku lokalnym oraz (jednocześnie) występujące w gminie bezrobocie w znacznym stopniu wpływa ujemnie na poziom życia wspólnoty samorządowej, a zastosowanie innych działań i wynikających

Tekst jedn.: Dz.U. z 2016 r., poz. 250 ze zm.

33 Zob. np.: C. Kosikowski, Komentarz do ustawy o gospodarce komunalnej oraz wzory aktów gminy dotyczqce przekształceń przedsiębiorstw komunalnych, Łódź-Zielona Góra 1997, s. 22; T. Skoczny, Dopuszczalność działalności gospodarczej gmin, „Samorząd Terytorialny” $1991 \mathrm{nr}$ 3, s. 4; W. Gonet, Ustawa o gospodarce komunalnej. Komentarz. Wzory umów i regulaminów, Warszawa 2010, s. 15; wyrok NSA w Gdańsku z dnia 9 stycznia 2003 r., SA/Gd 1968/02, OwSS 2003/4/105/105, OwSS 2004/2/49/49, LEX nr 79896.

34 Zgodnie z art. 9 ustawy o gospodarce komunalnej j.s.t. mogą tworzyć spółki z ograniczoną odpowiedzialnością lub spółki akcyjne, a także mogą przystępować do takich spółek. Jednostki samorządu terytorialnego mogą także tworzyć spółki komandytowe lub komandytowo-akcyjne, o których mowa w art. 14 ust. 1 ustawy z dnia 19 grudnia 2008 r. o partnerstwie publiczno-prywatnym (tekst jedn.: Dz.U. z 2015 r., poz. 696 ze zm.). 
z obowiązujących przepisów środków prawnych nie doprowadziło do aktywizacji gospodarczej, a w szczególności do znacznego ożywienia rynku lokalnego lub trwałego ograniczenia bezrobocia (por. art. 10 ust. 1 ustawy o gospodarce komunalnej) ${ }^{35}$. Województwo może prowadzić działalność gospodarczą poza sferą użyteczności publicznej, tworząc spółki z ograniczoną odpowiedzialnością i spółki akcyjne, oraz przystępować do nich, ale wyłącznie pod warunkiem, że działalność tych spółek polega na wykonywaniu czynności promocyjnych, edukacyjnych, wydawniczych oraz na wykonywaniu działalności w zakresie telekomunikacji służących rozwojowi województwa (por. art. 13 ust. 2 ustawy o samorządzie województwa). Natomiast powiat wcale nie może prowadzić działalności gospodarczej wykraczającej poza zadania o charakterze użyteczności publicznej (por. art. 6 ust. 2 ustawy o samorządzie powiatowym). Pozbawienie powiatu - jako jedynej j.s.t. - uprawnień do podejmowania zarobkowej (komercyjnej) działalności gospodarczej nie znajduje zdaniem autorów niniejszego opracowania racjonalnego uzasadnienia ${ }^{36}$. Dochody z działalności gospodarczej samorządu terytorialnego, bez względu na sferę tej działalności, zasilają budżety samorządowe ${ }^{37}$.

Co ciekawe, uprawnienia j.s.t. w dziedzinie gospodarki komunalnej i możliwości czerpania dochodów z działalności w niej prowadzonej są obecnie znacznie bardziej ograniczone niż odpowiednie uprawnienia w II Rzeczypospolitej - w okresie, w którym podejmowanie bezpośredniej działalności gospodarczej przez podmioty publiczne (państwo, samorząd terytorialny) budziło duże kontrowersje i uznawane było wielu przedstawicieli nauki polskiej i zachodnioeuropejskiej za przejaw etaty$z^{38} u^{38}$. Spory toczone $\mathrm{w}$ nauce na temat właściwości prowadzenia przez

35 Szerzej zob. np.: W. Gonet, Ustawa o gospodarce..., s. 64 i n.; C. Banasiński, M. Kulesza, Ustawa o gospodarce komunalnej. Komentarz, Warszawa 2002, s. 90 i n. Podobnie np.: A. Borodo, Samorzq̨d terytorialny..., 2012, s. 160; J. Jagoda, Komentarz do art. 6 ustawy o samorzqdzie powiatowym, [w:] B. Dolnicki (red.), Ustawa o samorzqdzie powiatowym. Komentarz, Warszawa 2007, LEX nr 30670.

37 Dotyczy to także spółek samorządowych. Zyski z działalności spółki mogą być kierowane na inwestycje spółki, a także na inne, ważne cele j.s.t., np. na inwestycje infrastrukturalne (zob. A. Borodo, Samorzq̨d terytorialny..., 2012, s. 162).

38 Zob. szerzej np.: K. Krzeczkowski, Zagadnienie przedsiębiorczości komunalnej, Warszawa 1934, s. 1 i n.; A. Heydel, T. Lulek, S. Schmidt, S. Wyrobisz, F. Zweig, 
j.s.t. działalności gospodarczej (w tym tworzenia i utrzymywania przedsiębiorstw samorządowych ${ }^{39}$ ) nie wywarły wpływu na przyjęte rozwiązania prawne ani na praktykę. W II RP j.s.t. przejawiały bowiem dużą aktywność w sprawach gospodarczych, a ówczesny prawodawca polski nie ustanowił żadnych zakazów lub ograniczeń odnoszących się do zakresu działalności gospodarczej j.s.t. ${ }^{40}$ Umożliwiało to organom samorządowym swobodne podejmowanie działalności gospodarczej o charakterze użyteczności publicznej oraz działalności, której głównym celem było przysparzanie j.s.t. dochodów, a więc komercyjnej działalności gospodarczej $^{41}$. Organy samorządowe dysponowały także swobodą w wyborze sposobów i form prowadzenia działalności gospodarczej ${ }^{42}$. Zadania z omawianej dziedziny mogły być wykonywane przez j.s.t. samodzielnie (przy pomocy przedsiębiorstwa założonego przez j.s.t. i prowadzonego w ramach samorządowej gospodarki budżetowej lub na zasadach prawa handlowego, a więc w formie spółki handlowej, której kapitał stanowił całkowitą własność założycielskiej j.s.t.) albo na zasadach współpracy z innymi podmiotami (organami administracji publicznej, innymi j.s.t., organizacjami społecznymi, podmiotami prywatnymi), przy wykorzystaniu różnych form prawnych, np. związku międzykomunalnego, spółdzielni, spółki handlowej o kapitale mieszanym, koncesji, umów cywilnoprawnych, por. np. art. 65 Konstytucji marcowej, przepisy ustawy z dnia

Etatyzm w Polsce, Kraków 1932; I. Weinfeld, Skarbowość polska. Przedsiębiorstwa Samorzq̨ - Ślqsk, Warszawa 1935, s. 360 i n.; J. Harasimowicz, Rozwój terenowego prawa finansowego w Polsce, Warszawa 1952, s. 11, 192 (przypis $\mathrm{nr}$ 175); T. Dębowska-

-Romanowska, Metody organizacji i finansowania przedsiębiorstw komunalnych w Polsce międzywojennej, „Zeszyty Naukowe Uniwersytetu Łódzkiego. Nauki Humanistyczno-Społeczne” 1970, nr 73, s. 16-18.

39 Pojęcia „przedsiębiorstwo samorządowe” i „przedsiębiorstwo komunalne” należy traktować równoznacznie.

40 Podobnie np.: M. Jaroszyński, Prawo o przedsiębiorstwach komunalnych, „Samorząd” $1933 \mathrm{nr}$ 4, s. 45 i n.; A. Młynarczyk, Ewolucja i kierunki uregulowań prawnych źródeł dochodów jednostek samorzq̨du terytorialnego, „Samorząd Terytorialny” 2002 nr 7-8, s. 116.

41 Podobnie np. A. Borodo, Samorzqd terytorialny..., 2012, s. 158.

42 Podobnie np. A. Młynarczyk, Formy gospodarki komunalnej w II Rzeczypospolitej, [w:] A. Borodo (red.), Zagadnienia prawne finansów i gospodarki samorzq̨du terytorialnego, Toruń 2008, s. 104. 
29 października 1920 r. o spółdzielniach (Dz.U. Nr 111, poz. 733 ze zm.), art. 43 ust. 1 pkt i, art. 44 ust. 1 pkt g ustawy scaleniowej, art. 6 ust. 1 ustawy z dnia 29 marca 1933 r. o rzeźniach z prawem wyłączności (Dz.U. Nr 32, poz. 280 z późn. zm.), art. 3, 33 ust. 1 ustawy z dnia 17 marca 1932 r. o koncesjach na koleje znaczenia miejscowego i koleje miejskie (Dz.U. Nr 38, poz. 391), przepisy ustawy z dnia 15 lutego 1933 r. o dostawach i robotach na rzecz Skarbu Państwa, samorządu oraz instytucji prawa publicznego (Dz.U. Nr 19, poz. 127), art. 1 rozporządzenia Prezydenta RP z dnia 22 marca 1928 r. o związkach międzykomunalnych (Dz.U. Nr 39, poz. 386 ze zm.), przepisy rozporządzenia Prezydenta RP z dnia 22 marca 1928 r. Prawo o spółkach akcyjnych (Dz.U. Nr 39, poz. 383 ze zm.), § 3 rozporządzenia Prezydenta RP z dnia 17 czerwca 1924 r., § 4, 5 rozporządzenia Ministra Spraw Wewnętrznych z dnia 28 czerwca 1926 r., § 4, 5 rozporządzenia Ministra Spraw Wewnętrznych z dnia 6 grudnia 1932 r.).

Warto zauważyć, że swoboda, jaką pozostawił prawodawca międzywojenny j.s.t. w dziedzinie gospodarki komunalnej, przyniosła intensywny rozwój działalności gospodarczej podejmowanej bezpośrednio przez j.s.t. ${ }^{43}$ Podobnie jak współcześnie, w II RP tworzenie przedsiębiorstw komunalnych (w tym - poza nielicznymi przypadkami ${ }^{44}$ - wybór formy organizacyjno-prawnej przedsiębiorstwa oraz wyposażanie go w składniki majątkowe), ich przekształcanie lub likwidacja należało do kompetencji organów samorządowych (por. np. art. 21 pkt 1 dekretu z 1919 r. o samorządzie miejskim, art. 43 ust. 1 pkt k ustawy scaleniowej $)^{45}$. W omawianym okresie historycznym za przedsiębiorstwa komunalne uważano:

43 Zob. szerzej np.: A. Dmitrjew, Przedsiębiorstwa komunalne..., s. 6; T. Dębowska-Romanowska, Metody organizacji..., s. 19-20.

44 Wyjątkami od nadawania przedsiębiorstwu komunalnemu formy prawnej w drodze swobodnej decyzji organu stanowiącego j.s.t. były przede wszystkim regulacje wyznaczające zasady organizacji komunalnych kas oszczędności, por. rozporządzenie Prezydenta Rzeczypospolitej z dnia 13 kwietnia 1927 r. o komunalnych kasach oszczędności (Dz.U. Nr 38, poz. 339 ze zm.). Problematyka kas komunalnych zostanie szerzej omówiona w dalszych rozważaniach.

45 Zob. szerzej np.: I. Weinfeld, Skarbowość polska..., s. 418; M. Jaroszyński, Prawo o przedsiębiorstwach..., s. 45-46. 
przedsiębiorstwa o charakterze zakładów użyteczności publicznej ${ }^{46}$ (zakłady wodociągowe, gazownie, elektrownie, rzeźnie, przedsiębiorstwa komunikacji publicznej itp.), przedsiębiorstwa przemysłowo-handlowe (np. cegielnie, kamieniołomy, instytucje kredytowe i ubezpieczeniowe, przedsiębiorstwa handlowe) oraz gospodarstwa rolne, leśne i rybne, które stanowiły samodzielne jednostki gospodarcze (por. § 5 rozporządzenia Ministra Spraw Wewnętrznych z dnia 28 czerwca 1926 r., § 5 rozporządzenia Ministra Spraw Wewnętrznych z dnia 6 grudnia 1932 r.) ${ }^{47}$. Obowiązywała ogólna, mająca zastosowanie do wszystkich przedsiębiorstw komunalnych, bez względu na rodzaj przedsiębiorstwa i nadaną mu formę organizacyjno-prawną, zasada samofinansowania (samowystarczalności finansowej) przedsiębiorstw komunalnych, tj. pokrywania dochodami przedsiębiorstwa co najmniej jego kosztów eksploatacyjnych łącznie z oprocentowaniem i amortyzacją kapitału zakładowego (por. art. 28 ust. 1 ustawy o tymczasowym uregulowaniu finansów komunalnych) ${ }^{48}$. Wprawdzie formalnie kształtowanie dochodów z przedsiębiorstw komunalnych było uzależnione od rodzaju przedsiębiorstwa ${ }^{49}$, jednak w prakty-

46 Pojęcia „przedsiębiorstwa komunalne o charakterze zakładów użyteczności publicznej” i „przedsiębiorstwa komunalne użyteczności publicznej” należy traktować równoznacznie.

47 Zob. też np.: A. Dmitrjew, Przedsiębiorstwa komunalne..., s. 37; T. Dębowska-Romanowska, Metody organizacji..., s. 21.

48 Zob. np. A. Borodo, Dochody samorzqdu terytorialnego w Polsce. Studium finansowoprawne, Toruń 1993, s. 58.

49 Zgodnie z zasadą wyrażoną w rozporządzeniu wykonawczym wydanym do ustawy o tymczasowym uregulowaniu finansów komunalnych j.s.t. miały czerpać zyski z przedsiębiorstw handlowo-przemysłowych, natomiast przedsiębiorstwa komunalne użyteczności publicznej miały być prowadzone jako „jednostki gospodarcze samodzielne i samowystarczalne, jednakowoż nie obliczone na zysk i nie traktowane jako komunalne źródła dochodów”, por. § 107 rozporządzenia Ministra Spraw Wewnętrznych z dnia 23 listopada 1932 r. wydanego w porozumieniu z Ministrem Skarbu celem wykonania ustawy z dnia 11 sierpnia 1923 r. o tymczasowem uregulowaniu finansów komunalnych (Dz.U. Nr 113, poz. 937 ze zm.; dalej: rozporządzenie wykonawcze do ustawy o tymczasowym uregulowaniu finansów komunalnych). Podobnie jak prawodawca przedstawiciele ówczesnej nauki podkreślali, że istotą przedsiębiorstw komunalnych użyteczności publicznej jest nie przynoszenie dochodów j.s.t., lecz realizacja interesu publicznego. Zob. np.: K. Krzeczkowski, Zagadnienie przedsiębiorczości..., s. 4; L.W. Biegeleisen, Zagadnienia ekonomiki..., s. 41 i n.; A. Dmitrjew, Przedsiębiorstwa komunalne..., 
ce organy samorządowe podejmowały działania zmierzające do osiągania wysokich dochodów z przedsiębiorstw komunalnych, także z komunalnych przedsiębiorstw użyteczności publicznej. Adam Ginsbert-Gebert podawał, że największe zyski generowały samorządowe elektrownie i zakłady wodociągowe, a więc przedsiębiorstwa zaspakajające najbardziej elementarne potrzeby ludności ${ }^{50}$. Naruszanie zasady niegenerowania zysków przez komunalne przedsiębiorstwa użyteczności publicznej związane było z trudnościami finansowymi j.s.t. w okresie II RP, spowodowanymi przede wszystkim kryzysem lat 20. i 30. XX wieku oraz zjawiskiem występującym także dzisiaj, tj. permanentnym naruszaniem zasady adekwatności zasobów finansowych j.s.t. do przydzielanych im zadań ${ }^{51}$. Dochody uzyskiwane z działalności gospodarczej samorządu terytorialnego zasilały (podobnie jak współcześnie) budżety samorządowe (por. np. § 4 rozporządzenia Prezydenta RP z dnia 17 czerwca 1924 r., § 4, 31 rozporządzenia Ministra Spraw Wewnętrznych z dnia 28 czerwca 1926 r., § 4, 31 rozporządzenia Ministra Spraw Wewnętrznych z dnia 6 grudnia 1932 r.). Należy dodać, że wysokość opłat i cen za usługi lub wyroby przedsiębiorstw komunalnych ustalały samodzielnie organy samorządowe (por. np. art. 21 pkt 9 dekretu z 1919 r. o samorządzie miejskim, art. 44 ust. 1 pkt e ustawy scaleniowej) ${ }^{52}$. Uchwały podejmowane w sprawach opłat i cen przedsiębiorstw komunalnych nie podlegały zatwierdzeniu władzy

s. 15; I. Weinfeld, Skarbowość polska..., s. 362, 363, 419; K. Romaniuk, Formy organizacyjne przedsiębiorstw komunalnych w Polsce, Warszawa 1933, s. 6.

Zob. A. Ginsbert-Gebert, Polityka komunalna, Warszawa 1977, s. 37-38.

51 Wspomniana zasada została ustanowiona w okresie II RP w art. 69 ustawy o tymczasowym uregulowaniu finansów komunalnych, a w III RP - w art. 167 ust. 1 i 4 Konstytucji RP.

Szerzej na temat trudności finansowych j.s.t. w okresie II RP i ich przyczyn zob. np.: K. Ostrowski, Polityka finansowa Polski przedwrześniowej, Warszawa 1958, s. 274 i n.; R. Szwed, Samorzqd terytorialny w Drugiej Rzeczypospolitej (1918-1939). Zarys problematyki, [w:] R. Szwed (red.), Samorzq̨dowa Rzeczypospolita 1918-1939. Wybór rozpraw i artykułów, Częstochowa 2000, s. 46 i n. Zagadnienie naruszania zasady adekwatności zasobów finansowych j.s.t. do nałożonych nań zadań w czasach dzisiejszych podejmuje np. H. Izdebski. Autor sporządza wykaz regulacji prawnych, na mocy których j.s.t. przydzielono nowe zadania własne bez zapewnienia dodatkowych środków finansowych (zob. H. Izdebski, Samorzq̨d terytorialny..., s. 336).

52 Zob. też np. A. Borodo, Dochody samorzq̨u..., s. 58. 
nadzorczej, jednak w sytuacji stwierdzenia nierespektowania zasady samofinansowania przedsiębiorstw komunalnych władza nadzorcza mogła nakazać podniesienie opłat i cen ${ }^{53}$.

W okresie II RP zdecydowanie dominowały przedsiębiorstwa komunalne prowadzone samodzielnie przez j.s.t., na zasadach prawa budżetowego samorządu terytorialnego ${ }^{54}$. W ramach gospodarki budżetowej j.s.t. mogły działać nie tylko przedsiębiorstwa użyteczności publicznej, ale także przedsiębiorstwa handlowe i przemysłowe, których celem działalności było przysparzanie j.s.t. dochodów (por. np. por. § 5 rozporządzenia Ministra Spraw Wewnętrznych z dnia 28 czerwca 1926 r. i § 5 rozporządzenia Ministra Spraw Wewnętrznych z dnia 6 grudnia 1932 r. w nawiązaniu do $\S 108$ rozporządzenia wykonawczego do ustawy o tymczasowym uregulowaniu finansów komunalnych). Dozwolone zatem było - w odróżnieniu od czasów dzisiejszych - prowadzenie w obrębie samorządowej gospodarki budżetowej przez j.s.t. komercyjnej działalności gospodarczej. Takie rozwiązanie nie wydaje się autorom niniejszego opracowania właściwe (racjonalne), uważamy bowiem, że działalność j.s.t. wykraczająca poza sferę użyteczności publicznej powinna być prowadzona na zasadach prawa handlowego.

Szczególnego rodzaju instytucjami samorządowymi działającymi w dziedzinie międzywojennej gospodarki lokalnej były niewystępujące obecnie komunalne, tj. miejskie, powiatowe i wojewódzkie, kasy oszczędności. W międzywojennej literaturze wspomniane kasy zaliczano do przedsiębiorstw komunalnych ${ }^{55}$. Natomiast rozporządzenie Prezydenta RP z dnia 13 kwietnia 1927 r. o komunalnych kasach oszczędności ${ }^{56}$ na-

53 Jak wynika z przeprowadzonych rozważań, organy nadzorujące działalność finansową j.s.t. nie miały uprawnień do wnioskowania o obniżenie opłat lub cen przedsiębiorstw komunalnych. Brak takich uprawnień krytykował np. A. Dmitrjew (zob. A. Dmitrjew, Przedsiębiorstwa komunalne..., s. 59).

54 Zob. szerzej K. Romaniuk, Formy organizacyjne..., s. 13 i n. (w tym tabela na s. 15), s. 37.

55 Zob. np.: A. Dmitrjew, Przedsiębiorstwa komunalne..., s. 71, 73-74; K. Romaniuk, Formy organizacyjne..., s. 22. O kasach jako przedsiębiorstwach komunalnych (wyposażonych $\mathrm{w}$ osobowość publicznoprawną) pisze też np. T. DębowskaRomanowska (zob. np. T. Dębowska-Romanowska, Metody organizacji..., s. 25).

56

Dalej: rozporządzenie Prezydenta RP o k.k.o. 
zywało kasy komunalnymi zakładami (por. art. 1 zd. 1 rozporządzenia). Kasy realizowały zadania polegające na wspieraniu lokalnego rozwoju, zwłaszcza w dziedzinie handlu, rzemiosła i przemysłu (por. art. 1 zd. 2 rozporządzenia Prezydenta RP o k.k.o.) $)^{57}$.

Komunalne kasy oszczędności miały (na mocy powołanego rozporządzenia Prezydenta RP) przyznaną osobowość prawną, dysponowały majątkiem wydzielonym z majątku macierzystej j.s.t., prowadziły samodzielną gospodarkę finansową, były zarządzane przez własne organy, którymi były rada kasy (organ stanowiący w sprawach kasy) i zarząd kasy (organ wykonawczy) (por. art. 1, 5, 12 rozporządzenia Prezydenta Rzeczypospolitej z dnia 13 kwietnia 1927 r.). ${ }^{58}$ Komunalne kasy oszczędności mogły być tworzone samodzielnie przez j.s.t. albo na zasadzie współdziałania z innymi j.s.t. (por. art. 3 rozporządzenia Prezydenta RP o k.k.o.). Uchwały o utworzeniu komunalnej kasy oszczędności podlegały zatwierdzeniu władzy nadzorczej (por. art. 10 rozporządzenia Prezydenta RP o k.k.o.). Założycielska j.s.t. odpowiadała za zobowiązania komunalnej kasy oszczędności z tytułu wkładów oszczędnościowych. W przypadku utworzenia kasy wspólnie z inną j.s.t. lub innymi j.s.t., odpowiedzialność ta spadała solidarnie na wszystkie j.s.t. organizujące kasę (por. art. 4 rozporządzenia Prezydenta RP o k.k.o.) ${ }^{59}$. Organem kontrolującym prawidłowość działania komunalnej kasy oszczędności była komisja rewizyjna,

Geneza międzywojennych komunalnych kas oszczędności sięga czasów zaborów (szerzej zob. P. Ruczkowski, Komunalne kasy oszczędności w Drugiej Rzeczypospolitej, ustrój prawny i działalność, Sandomierz 2010, s. 21 i n.). W II RP, w okresie poprzedzającym wprowadzenie rozporządzenia Prezydenta RP o k.k.o. źródła prawa komunalnych kas oszczędności były ustanowione odmiennie w poszczególnych dzielnicach kraju. Powołane rozporządzenie Prezydenta RP ujednoliciło zasady organizacji kas (zob. szerzej np.: A. Młynarczyk, Komunalne kasy oszczędności i banki samorzq̨dowe - zagadnienia prawne, Szczecin 2005, s. 7 i n.; taż, Działalność komunalnych kas oszczędności w II Rzeczypospolitej, „Samorząd Terytorialny” 2001 nr 7-8, s. 108; P. Ruczkowski, Komunalne kasy..., s. 49 i n.; A.W. Zawadzki, Finanse samorzq̨du..., s. 128-129).

57 A. Młynarczyk, Banki samorzq̨dowe - zagadnienie ich powołania, zadań, charakteru i pozycji, [w:] A. Borodo, Samorzq̨d terytorialny a banki, Toruń 2002, s. 65.

58 Szerzej zob. np.: A. Dmitrjew, Przedsiębiorstwa komunalne..., s. 40, 53, 71 i n., 80 i n.; K. Romaniuk, Formy organizacyjne.., s. 22-24; P. Ruczkowski, Komunalne kasy..., s. 61-64, 73 i n., 88; A. Młynarczyk, Działalność komunalnych..., s. 109.

Szerzej zob. P. Ruczkowski, Komunalne kasy..., s. 72-73. 
powoływana przez organ stanowiący j.s.t. (por. art. 6 rozporządzenia Prezydenta RP o k.k.o. $)^{60}$. Nadzór państwowy nad komunalnymi kasami oszczędności sprawował Minister Spraw Wewnętrznych działający w porozumieniu z Ministrem Skarbu ${ }^{61}$. Omawiane kasy nie działały dla osiągania zysków, a ewentualne nadwyżki bilansowe przeznaczały na fundusze rezerwowe albo na cele użyteczności publicznej ${ }^{62}$. Specjalnością kas były kredyty dla samorządów lokalnych ${ }^{63}$. Działalność komunalnych kas miała zatem istotne znaczenie w zaspakajaniu potrzeb j.s.t. na środki o charakterze zwrotnym, w tym na kredyty na realizowane inwestycje samorządowe (por. art. 24, 25 rozporządzenia Prezydenta RP o k.k.o.) ${ }^{64}$. Komunalne kasy oszczędności wywierały również istotny wpływ na działania w sferze gospodarki podejmowane przez mieszkańców j.s.t. Przyjmując terminowe i bezterminowe wkłady oszczędnościowe, kasy rozwijały idee oszczędności, a udzielając mieszkańcom j.s.t. niskooprocentowanych kredytów, stymulowały rozwój miejscowego rzemiosła handlu, przemysłu, małych i średnich gospodarstw rolnych ${ }^{65}$. Warto zauważyć, że państwo wspierało działalność komunalnych kas oszczędności przez przyznanie im licznych ulg i zwolnień podatkowych, m.in. kasy zwolnione były od państwowych podatków dochodowego, od darowizn, przemysłowego, od dodatków komunalnych do ww. podatków państwowych, od opłat stemplowych od podań wnoszonych przez kasy komunalne (por. art. 28 rozporządzenia Prezydenta RP o k.k.o.) ${ }^{66}$.

60 Tamże, s. 85-86.

61 Szerzej zob. np. M. Młynarczyk, Działalność komunalnych..., s. 109; P. Ruczkowski, Komunalne kasy..., s. 105 i n.

62 A. Młynarczyk, Komunalne kasy..., s. 10 (i przywołana tam literatura).

63 A.W. Zawadzki, Finanse samorzqdu..., s. 128; A. Młynarczyk, Działalność komunalnych..., s. 111; taż, Komunalne kasy..., s. 14.

64 Szerzej zob. np.: A. Młynarczyk, Banki samorzqdowe..., s. 66-67; taż, Komunalne kasy..., s. 13-14. Autorka porusza także zagadnienie nieprawidłowości jakie występowały w praktyce przy udzielaniu j.s.t. kredytów przez komunalne kasy oszczędności (zob. A. Młynarczyk, Komunalne kasy..., s. 14-15; taż, Działalność komunalnych..., s. 111-112).

65 Szerzej na temat działalności komunalnych kas oszczędności zob. np.: A. Młynarczyk, Komunalne kasy..., s. 10 i n.; P. Ruczkowski, Komunalne kasy..., s. 89 i n.

66 Zob. szerzej np.: A. Młynarczyk, Komunalne kasy..., s. 16-18; P. Ruczkowski, Komunalne kasy..., s. 104-105. 
W czasach współczesnych, pomimo podejmowanych inicjatyw ustawodawczych oraz postulatów przedstawicieli nauki, nie przyjęto - jak sygnalizowano wcześniej - regulacji prawnych pozwalających j.s.t. na tworzenie instytucji stanowiących odpowiedniki międzywojennych komunalnych kas oszczędności ${ }^{67}$. Należy w tym miejscu podkreślić, że komunalne kasy oszczędności występują w wielu krajach Europy, a za jeden z najsprawniej funkcjonujących systemów komunalnych kas oszczędności uważany jest system niemiecki ${ }^{68}$. Wprawdzie w naszym kraju, w aktualnym stanie prawnym, j.s.t., zwłaszcza gminy, uprawnione są do prowadzenia działalności bankowej, w formie spółek handlowych (por. np. art. 12, art. 13 ust. 1 ustawy z dnia 29 sierpnia 1997 Prawo bankowe ${ }^{69}$, art. 10 ust. 3 ustawy o gospodarce komunalnej $)^{70}$, to wydaje się jednak, że taka działalność gospodarcza podejmowana przez gminy ma mieć charakter komercyjnej działalności gospodarczej, nie zaś - jak to było w II RP charakter użyteczności publicznej ${ }^{71}$.

\section{Zakończenie}

Przeprowadzone w ramach niniejszego opracowania badania potwierdziły, że w czasach współczesnych j.s.t. dysponują węższym zakresem swo-

67 Zob. np.: Sejm RP, 1 kadencja, Poselski projekt o komunalnych kasach oszczędności, druk sejmowy z 1992 r. nr 73; A. Młynarczyk, Rola komunalnych kas oszczędności we wspieraniu rozwoju gospodarki lokalnej, „Samorząd Terytorialny” 2006, nr 6, s. 57 i n.; A. Borodo, Samorzq̨d terytorialny..., 2012, s. 162.

68 Zob. np. A. Borodo, Samorzq̨d terytorialny..., s. 162; C. Banasiński, M. Kulesza, Ustawa o gospodarce..., s. 93; na temat współczesnego systemu komunalnych kas oszczędności w Niemczech zob. szerzej np. A. Młynarczyk, Komunalne kasy..., s. 31 i n.

69 Tekst jedn.: Dz.U. z 2015, poz. 128 ze zm.

70 Zgodnie z ustawą Prawo bankowe czynności bankowe obejmują m.in.: przyjmowanie wkładów pieniężnych płatnych na żądanie lub z nadejściem oznaczonego terminu oraz prowadzenie rachunków tych wkładów, udzielanie kredytów, emitowanie papierów wartościowych (por. art. 5 ust. 1 ustawy).

Szerzej na temat regulacji prawnych umożliwiających tworzenie samorządowych instytucji bankowych zob. np.: A. Młynarczyk, Banki samorzqdowe..., s. 61-62; taż, Komunalne kasy..., s. 54-55; M. Szydło, Ustawa o gospodarce..., Komentarz do art. 2 ustawy o gospodarce komunalnej.

71 Podobnie np.: A. Młynarczyk, Komunalne kasy..., s. 55-56; taż, Banki samorzqdowe..., s. 63. 
body w prowadzeniu działalności gospodarczej niż j.s.t. w okresie II RP, co bez wątpienia przedkłada się na mniejsze możliwości osiągania dochodów z tej działalności. Wynika to przede wszystkim z ograniczeń i zakazów, jakie współczesny prawodawca polski ustanowił w sferze działalności gospodarczej samorządu terytorialnego wykraczającej poza sferę użyteczności publicznej. Ograniczenia te i zakazy są źródłem ambiwalentnych refleksji. Z jednej bowiem strony trudno pozostać obojętnym na poważne problemy finansowe, $\mathrm{z}$ jakimi borykają się współcześnie j.s.t., wynikające $\mathrm{w}$ dużym stopniu $\mathrm{z}$ naruszania konstytucyjnej zasady adekwatności zasobów finansowych j.s.t. do przydzielanych im zadań. Gospodarka komunalna jest bez wątpienia tą dziedziną, w której j.s.t. powinny mieć możliwość podejmowania różnorodnych inicjatyw, w tym także prowadzenia działalności gospodarczej mającej na celu przysparzanie wspólnocie samorządowej dochodów. Z drugiej jednak strony zbyt duża swoboda w zakresie takiej działalności rodzi niebezpieczeństwo wypaczenia zasadniczej roli samorządu terytorialnego, jaką jest wykonywanie zadań mających na celu bezpośrednie zaspokajanie potrzeb mieszkańców wspólnot samorządowych, oraz zagrożenie zmonopolizowania niektórych dziedzin gospodarki lokalnej, wynikające $\mathrm{z}$ możliwości bezprawnego wykorzystywania przez j.s.t. ich uprzywilejowanej pozycji. Jak się wydaje, warto byłoby wprowadzić do naszej regulacji prawnej rozwiązania kompromisowe, takie jak np. stworzenie j.s.t. możliwości zakładania i prowadzenia komunalnych kas oszczędności. Można by w tym wypadku skorzystać z rozwiązań zastosowanych w II RP oraz we współczesnym systemie niemieckim. Komunalne kasy oszczędności powinny mieć - dla możliwości samodzielnego działania - nadaną osobowość prawną, być instytucjami użyteczności publicznej działającymi w dziedzinie bankowości, a więc - wzorem polskich kas międzywojennych i współczesnych niemieckich - nie działać dla osiągnięcia zysku, lecz dla realizacji dobra publicznego. Działalność kas powinna ponadto podlegać kontroli organów samorządowych oraz nadzorowi sprawowanemu w ramach systemu bankowego. Bez wątpienia należy także znieść - jako rozwiązanie nieznajdujące racjonalnego uzasadnienia - zakaz prowadzenia przez powiaty działalności wykraczającej poza sferę użyteczności publicznej. 
Dochody z działalności gospodarczej samorzq̨u...

\section{Bibliografia:}

Banasiński C., Kulesza M., Ustawa o gospodarce komunalnej. Komentarz, Wydawnictwo ABC, Warszawa 2002.

Biegeleisen L.W., Zagadnienia ekonomiki komunalnej, Wydawnictwo Związku Pracowników Administracji Gminnej Rzeczypospolitej Polskiej, Warszawa 1928.

Bigo T., Związki publiczno-prawne w świetle ustawodawstwa polskiego, Wydawnictwo Kasy im. Mianowskiego, Warszawa 1928.

Borodo A., Dochody samorzqdu terytorialnego w Polsce. Studium finansowoprawne, Uniwersytet Mikołaja Kopernika, Toruń 1993.

Borodo A., Samorzq̨ terytorialny. System prawnofinansowy, Wydawnictwo Prawnicze LexisNexis, Warszawa 2004.

Borodo A., Samorzqd terytorialny. System prawnofinansowy, LexisNexis Polska Sp. z.o.o., Warszawa 2012.

Czarnow S., Działalność gospodarcza jednostek samorzqdu terytorialnego, „Samorząd Terytorialny” 2007, nr 10, s. 22-37.

Dębowska-Romanowska T., Metody organizacji i finansowania przedsiębiorstw komunalnych w Polsce międzywojennej, „Zeszyty Naukowe Uniwersytetu Łódzkiego. Nauki Humanistyczno-Społeczne” 1970, nr 73, s. 15-39.

Dmitrjew A., Przedsiębiorstwa komunalne w ustawodawstwie polskiem (studjum finansowe), Skład Główny w Księgarni Kazimierza Rutskiego, Wilno 1934.

Ginsbert-Gebert A., Polityka komunalna, Państwowe Wydawnictwo Ekonomiczne, Warszawa 1977.

Gonet W., Ustawa o gospodarce komunalnej. Komentarz. Wzory umów i regulaminów, Lexis Nexis Polska Sp. z o.o., Warszawa 2010.

Harasimowicz J., Rozwój terenowego prawa finansowego w Polsce, Polskie Wydawnictwa Gospodarcze, Warszawa 1952.

Izdebski H., Samorzq̨d terytorialny. Podstawy ustroju i działalności, Wydawnictwo LexisNexis, Warszawa 2011.

Jagoda J., Komentarz do art. 6 ustawy o samorzqdzie powiatowym, [w:] B. Dolnicki (red.), Ustawa o samorzqdzie powiatowym. Komentarz, Wolters Kluwer Polska, Warszawa 2007, System Informacji Prawnej LEX nr 30670.

Janku Z., Samodzielność jednostek samorzqdu terytorialnego a istota nadzoru, ze szczególnym uwzględnieniem nadzoru regionalnej izby obrachunkowej, [w:] J. Małecki, R. Hauser, Z. Janku (red.), 15 lat funkcjonowania izb obrachunkowych, Wydawnictwo UNI-DRUK Sp. j., Poznań 2007. 
Jaroszyński M., Prawo o przedsiębiorstwach komunalnych, „Samorząd” 1933, nr 4, s. 45-47.

Kallas M., Krzymkowski M., Historia ustroju i prawa w Polsce 1772/1795-1918, Wydawnictwo Naukowe PWN S.A., Warszawa 2006.

Kołaczkowski B., Ratajczak M., Gospodarka finansowa samorzqdu terytorialnego w Polsce, Wolters Kluwer, Warszawa 2010.

Kołaczkowski B., Ratajczak M., Samorzqd terytorialny w zaborze rosyjskim? Poczq̨tki decentralizacji administracji terenowej w Królestwie Polskim i na Ziemiach Zabranych w latach 1861-1915, „Samorząd Terytorialny” 2013, nr 7-8, s. 154-170.

Kosikowski C., Finanse publiczne w świetle Konstytucji RP oraz orzecznictwa Trybunału Konstytucyjnego, Wydawnictwo Sejmowe, Warszawa 2004.

Kotulski M., Pojęcie i istota samorzq̨du terytorialnego, „Samorząd Terytorialny” 2000, nr 1-2, s. 82-90.

Krzeczkowski K., Zagadnienie przedsiębiorczości komunalnej, odbitka z „Samorządu Terytorialnego”, Warszawa 1934.

Markowski B., Finanse samorzq̨du terytorjalnego (1919-1928), [w:] S.L. Zaleski (red.), Bilans gospodarczy dziesięciolecia Polski odrodzonej, Skład Główny Gebethner i Wolf Warszawa-Poznań, Poznań 1929.

Młynarczyk A., Banki samorzq̨dowe - zagadnienie ich powołania, zadań, charakteru i pozycji, [w:] A. Borodo, Samorzqd terytorialny a banki, TNOiK, Toruń 2002.

Młynarczyk A., Działalność komunalnych kas oszczędności w II Rzeczypospolitej, „Samorząd Terytorialny” 2001, nr 7-8, s. 108-114.

Młynarczyk A., Ewolucja i kierunki uregulowań prawnych źródeł dochodów jednostek samorzq̨du terytorialnego, „Samorząd Terytorialny” 2002, nr 7-8, s. $108-118$.

Młynarczyk A., Formy gospodarki komunalnej w II Rzeczypospolitej, [w:] A. Borodo (red.), Zagadnienia prawne finansów i gospodarki samorzqdu terytorialnego, TNOiK, Toruń 2008.

Młynarczyk A., Komunalne kasy oszczędności i banki samorzq̨owe - zagadnienia prawne, Kampol, Szczecin 2005.

Ostrowski K., Polityka finansowa Polski przedwrześniowej, Państwowe Wydawnictwo Naukowe, Warszawa 1958.

Romaniuk K., Formy organizacyjne przedsiębiorstw komunalnych w Polsce, odbitka z Kwartalnika statystycznego, wydawanego przez Główny Urząd Statystyczny, Warszawa 1933. 
Skibiński A., Samodzielność samorzq̨du terytorialnego $w$ Polsce $w$ świetle ukształtowanego nadzoru, s. 202 i n., [w:] J. Małecki, R. Hauser, Z. Janku (red.), 15 lat funkcjonowania izb obrachunkowych, UNI-DRUK Sp. j., Poznań 2007.

Starzyński L., Prawo budżetowe zwiq̨zków samorzq̨dowych, [w:] L. Starzyński i F. Grela, Prawo budżetowe oraz przepis o kasowości i rachunkowości zwiq̨zów samorzq̨dowych, Samorządowy Instytut Wydawniczy, Warszawa 1933.

Szwed R., Samorzqd terytorialny w Drugiej Rzeczypospolitej (1918-1939). Zarys problematyki, [w:] R. Szwed (red.), Samorządowa Rzeczypospolita 1918-1939. Wybór rozpraw i artykułów, Wydawnictwo Wyższej Szkoły Pedagogicznej w Częstochowie, Częstochowa 2000.

Szydło M., Ustawa o gospodarce komunalnej. Komentarz, Wolters Kluwer, Warszawa 2008, System Informacji Prawnej LEX nr 37176.

Weinfeld I., Skarbowość polska. Przedsiębiorstwa - Samorzq̨d - Ślq̨sk, Wydawnictwo „Biblioteka Prawnicza”, Warszawa 1935.

Witkowski W., Historia administracji w Polsce 1764-1989, Wydawnictwo Naukowe PWN, Warszawa 2007.

Zawadzki A.W., Finanse samorzqdu w latach 1918-1939, Państwowe Wydawnictwo Ekonomiczne, Warszawa 1971. 